\title{
New records of Hydraenidae and Dryopidae (Coleoptera) from the Caucasus
}

\section{Новые указания Hydraenidae и Dryopidae (Coleoptera) с Кавказа}

\author{
Alexander A. Prokin ${ }^{1}$, Maxim I. Shapovalov' ${ }^{2}$ Manfred A. Jäch ${ }^{3}$ \\ А.А. Прокин, М.И. Шаповалов, М.А. Ех
}

\footnotetext{
${ }^{1}$ Papanin Institute for Biology of Inland Waters, Russian Academy of Sciences, Borok, Nekouzsky District, 152742, Yaroslavl Oblast', Russia. E-mail: prokina@mail.ru

2 Adyghe State University, Maikop 385000, Republic of Adygea, Russia. E-mail: shapmaxim2017@yandex.ru

${ }^{3}$ Naturhistorisches Museum Wien, Burgring 7, A-1010 Wien, Austria. E-mail: manfred.jaech@nhm-wien.ac.at

${ }^{1}$ Институт биологии внутренних вод им. И.Д. Папанина РАН, 152742 Ярославская обл., Некоузский р-н., Борок, Россия.

2 Адыгейский государственный университет, 385000 Майкоп, Адыгея, Россия.
}

KEY WORDS: Coleoptera, Hydraenidae, Dryopidae, new records, Caucasus, Russia, Adygea, Krasnodarsky Kray, Abkhazia, South Ossetia.

КЛЮЧЕВЫЕ СЛОВА: Coleoptera, Hydraenidae, Dryopidae, новые указания, Кавказ, Россия, Адыгея, Краснодарский Край, Абхазия, Южная Осетия.

ABSTRACT. New data on the distribution of seven species of Hydraenidae and three species of Dryopidae from Russian Caucasus, Abkhazia and South Ossetia are provided. Hydraena anatolica Janssens, 1963, Limnebius myrmidon Rey, 1883, Ochthebius adventicius Jäch, 1990, O. colveranus (Ferro, 1979) and O. difficilis Mulsant, 1844 are recorded from Russia for the first time. Other new records are: Dryops nitidulus (Heer, 1841) (South European Territory of Russia), D. rufipes (Krynicki, 1832) and Limnebius myrmidon (Abkhazia) and D. similaris Bollow, 1936 (South Ossetia). The presence of $H$. canakcioglui aydini Janssens, 1968 in Krasnodarsky Kray and H. dentipalpis Reitter, 1888 in Adygea is confirmed.

РЕЗЮМЕ. Приводятся новые данные о распространении семи видов Hydraenidae и трёх Dryopidae на территории российского Кавказа, Абхазии и Южной Осетии. Hydraena anatolica Janssens, 1963, Limnebius myrmidon Rey, 1883, Ochthebius adventicius Јдсh, 1990, O. colveranus (Ferro, 1979) и О. difficilis Mulsant, 1844 впервые указаны для России; Dryops nitidulus (Heer, 1841) - для юга европейской части России; D. rufipes (Krynicki, 1832) и Limnebius myrmidon - для Абхазии, D. similaris Bollow, 1936 - для Южной Осетии. Новыми находками подтверждено обитание H. canakcioglui aydini Janssens, 1968 в Краснодарском крае, $H$. dentipalpis Reitter, 1888 - в Адыгее.

\section{Introduction}

Catalogues providing information about the occurrence of the species in the Caucasian countries were published by Jäch and Skale [2015] (Hydraenidae) and by Kodada and Jäch [2016] (Dryopidae).
In recent years, several publications have appeared that summarize data on the Hydraenidae of Turkey [Ertorun et al., 2011], Armenia [Jäch, Skale, 2011], and the Dryopidae of Iran [Mascagni et al., 2016]. Some records of Caucasian Dryopidae were also published by Zaitzev [1934], Nikitsky et al. [2010b], and Shapovalov et al., [2012], but the knowledge of the faunal composition of these families in the Russian part of the Caucasus, as well as in Abkhazia and South Ossetia (former parts of the Soviet Union, which were included in Georgia) is still quite incomplete.

\section{Material}

This paper is based mainly on material collected by the first two authors, i.e., by Maxim Shapovalov in Krasnodarsky Kray and Adygea, 2011-2015, and by Alexander Prokin in South Ossetia in May 2016 and in Abkhazia and Krasnodarsky Kray in August 2016.

The specimens are deposited in the collections of the first two authors and in the Naturhistorisches Museum Wien (Vienna, Austria).

\section{Results}

\section{Family Hydraenidae Mulsant, 1844}

Hydraena anatolica Janssens, 1963

MATERIAL. Russia, Adygea, Maikop Distr., Sibir' River, $44^{\circ} 9^{\prime}$ 19.6"N, 406'37.1" E, $550 \mathrm{~m}$ alt., 6.IV.2013, leg. M.Saprykin, 3 exs.; Russia, Krasnodarsky Kray, Akhmetovskaya, Etsokha River downstream of Garnukha River mouth, $\mathrm{T}=15.8^{\circ} \mathrm{C}, 44^{\circ} 9^{\prime} 1.27^{\prime \prime} \mathrm{N}, 41^{\circ} 2^{\prime}$ 31.9"E, 19.VII.2013 leg. M.Shapovalov \& M.Saprykin, 2 exs.; Russia,

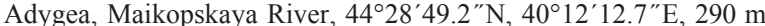
alt., 27.X.2013 leg. M.Shapovalov, M.Saprykin, A.Motorin, 4 exs. NOTE. New for Russia! 


\section{Hydraena dentipalpis Reitter, 1888}

MATERIAL. Russia, Adygea, near Novosvobodnaya village, Phars (Fars) River, 442'16.2"N, 40²4'47.5"E, 14.III.2013, leg. M.Shapovalov, M.Saprykin, A. Motorin, 4 exs.; Russia, Adygea, near Kamennomostsky village, Mishoko River, downstream of waterfall "Amphiteatr", $\mathrm{T}=3.5-4.3^{\circ} \mathrm{C}, 44^{\circ} 16^{\prime} 41.0^{\prime \prime} \mathrm{N}, 40^{\circ} 11^{\prime} 20.8^{\prime \prime} \mathrm{E}$ $450 \mathrm{~m}$ alt., 10.XII.2008, leg. M.Shapovalov, A.Motorin, 3 exs.

NOTE. This species was recorded from Adygea with a question mark by Nikitsky et al. [2010].

\section{Hydraena canakcioglui aydini Janssens, 1968}

MATERIAL. Russia, Krasnodarsky Kray, Il' River upstream Il'skyi village, $44^{\circ} 47^{\prime} 25.1^{\prime \prime} \mathrm{N}, 38^{\circ} 31^{\prime} 52.0^{\prime \prime} \mathrm{E}$, 17.VIII.2016, leg. A.Prokin, 1 ex.

NOTE. Hydraena canakcioglui aydini was recorded from Krasnodarsky Kray only once [Prokin et al., 2016].

\section{Limnebius myrmidon Rey, 1883}

MATERIAL. Abkhazia, Uakumi River near Achguara, small shallow pools at river bank, 42 ${ }^{\circ} 41^{\prime} 13.9^{\prime \prime} \mathrm{N}, 41^{\circ} 37^{\prime} 17.4^{\prime \prime} \mathrm{E}, 23$.VIII.2016, leg. A.Prokin, 25 exs.; Russia, Krasnodarsky Kray, Bolshaya Khosta River, near Krasnaya Volya, small shallow pools at river bank, 433' $02.5^{\prime \prime} \mathrm{N}, 39^{\circ} 53^{\prime} 38.8^{\prime \prime} \mathrm{E}, 21$.VIII.2016, leg. A.Prokin, 15 exs.; Russia, Krasnodarsky Kray, Agoy River near Tuapse, small shallow

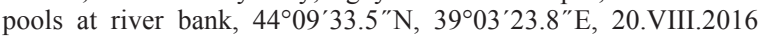
leg. A.Prokin, 18 exs.; Russia, Krasnodarsky Kray, Il' River upstream Il'skyi village, small shallow pools at river bank, $44^{\circ} 47^{\prime} 25.1^{\prime \prime} \mathrm{N}, 38^{\circ} 31^{\prime} 52.0^{\prime \prime} \mathrm{E}, 17 . \mathrm{VIII} .2016$, leg. A.Prokin, 22 exs.; Russia, Krasnodarsky Kray, Pshekha River upstream of Apsheron-

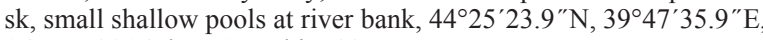
16.VIII.2016, leg. A.Prokin, 33 exs.

NOTE. New for Russia and Abkhazia! L. myrmidon is in need of taxonomic revision. Possibly, the Russian populations represent an undescribed species.

\section{Ochthebius adventicius Jäch, 1990}

MATERIAL. Russia, Krasnodarsky Kray, near Krasny Dagestan village, Kurdzhips River bank, pool, 4420'8.2"N, 3957'17.6"E, 29.VI.2015, leg. M.Shapovalov, M.Saprykin, 4 exs.

NOTE. New for Russia!

\section{Ochthebius colveranus (Ferro, 1979)}

MATERIAL. Russia, Adygea, near Novosvobodnaya village, Phars (Fars) River, 4422' 16.2"N, 40²4'47.5"E, 14.III.2013, leg. M.Shapovalov, M.Saprykin, A.Motorin, 3 exs.; Russia, Krasnodarsky Kray, near Makhoshevskaya village, Phars (Fars) River, 4434'29.4"N $40^{\circ} 27^{\prime} 27.1^{\prime \prime}$ E, 25.VI.2011, leg. M.Shapovalov, 2 exs.

NOTE. New for Russia!

Ochthebius difficilis Mulsant, 1844

MATERIAL. Russia, Krasnodarsky Kray, Neberdzhay River

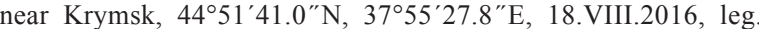
A.Prokin, 5 exs.

NOTE. New for Russia!

\section{Family Dryopidae Billberg, 1820}

\section{Dryops nitidulus (Heer, 1841)}

MATERIAL. Russia, Krasnodarsky Kray, tributary of Agoy

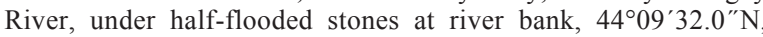
3903'47.2"E, 20.VIII.2016, leg. A.Prokin, 7 exs.; Russia, Krasnodarsky Kray, Shebsh River - tributary of Aphips River, near Stavropolskaya village, under half-flooded stones at river bank, 444ㄴ $08.2^{\prime \prime} \mathrm{N}, 38^{\circ} 50^{\prime} 13.6^{\prime \prime} \mathrm{E}, 17 . \mathrm{VIII} .2016$, leg. A.Prokin, 8 exs.

NOTE. New for South European Territory of Russia!

$$
\text { Dryops rufipes (Krynicki, 1832) }
$$

MATERIAL. Abkhazia, Uakumi River near Achguara, under half-flooded stones at river bank, 42 $41^{\prime} 13.9^{\prime \prime} \mathrm{N}, 41^{\circ} 37^{\prime} 17.4^{\prime \prime} \mathrm{E}$,
23.VIII.2016, leg. A.Prokin, 10 exs.; Abkhazia, Gumista River near mouth, under half-flooded stones at river bank, $43^{\circ} 02^{\prime} 18.6^{\prime \prime} \mathrm{N}$, $40^{\circ} 58^{\prime} 07.3$ "E, 22.VIII.2016, leg. A.Prokin, 12 exs.

NOTE. New for Abkhazia! This species was not yet recorded from Georgia. This species is in need of taxonomic revision.

\section{Dryops similaris Bollow, 1936}

MATERIAL. South Ossetia, Ertso Lake, on submerged wood among flooded Sphagnum papillosum, 42 ${ }^{\circ} 28^{\prime} 24.7^{\prime \prime} \mathrm{N}, 43^{\circ} 45^{\prime} 05.7^{\prime \prime} \mathrm{E}$, $1720 \mathrm{~m}$ alt., 07.V.2016, leg. A.Prokin, 7 exs.

NOTE. New for South Ossetia! This species was not yet recorded from Georgia.

For Hydraena anatolica and Ochthebius adventicius the records provided here significantly expand their known ranges.

By now, the fauna of Russia includes 71 species of Hydraenidae and 11 species of Dryopidae. The Hydraenidae and Dryopidae of Abkhazia and South Ossetia are still very poorly known. Dryops viennensis Castelnau, 1840 and D. caspius (Ménétriés, 1832) were recorded from Abkhazia by Zaitzev [1934], but these records need confirmation.

ACKNOWLEDGEMENTS. This study was supported by the Russian Science Foundation, project no. 15-14-10020.

\section{References}

Ertorun N., Jäch M.A., Kasapoğlu A., Darılmaz M.C. 2011. Checklist of the Hydraenidae (Coleoptera) of Turkey, with notes on distribution // Zootaxa. Vol.3055. P.22-42

Jäch M.A., Skale A. 2011. Annotated checklist of the Hydraenidae of Armenia (Coleoptera: Hydraenidae) // Koleopterologische Rundschau. Bd.81. S.93-111.

Jäch M.A., Skale A. 2015. Family Hydraenidae Mulsant, 1844 // Löbl I., Löbl D. (eds.). Catalogue of Palaearctic Coleoptera. Vol. 2/1. Revised and Updated Edition. Leiden-Boston: Brill. P.130-162.

Kodada J., Jäch M.A. 2016. Dryopidae // Löbl I., Löbl D. (eds.). Catalogue of Palaearctic Coleoptera, Vol. 3. Scarabaeoidea Scirtoidea - Dascilloidea - Buprestoidea - Byrrhoidea. Revised and updated edition. Leiden: Brill. P.603-607.

Mascagni A., Jäch M.A., Ostovan H., Ghahari H. 2016. Annotated checklist of Dryopidae and Heteroceridae (Coleoptera: Byrrhoidea) of Iran // Zootaxa. Vol.4144. No.3. P.354-364.

Nikitsky N.B., Prokin A.A., Shapovalov M.I. 2010a. Family Hydraenidae // Zamotajlov A.S., Nikitsky N.B. (eds.). Coleopterous insects (Insecta, Coleoptera) of Republic of Adyghea (annotated catalogue of species). Maikop: Adyghe State University Publishers. P.70-71 [in Russian, with English Title].

Nikitsky N.B., Prokin A.A., Shapovalov M.I. 2010b. Family Dryopidae. In: Zamotajlov A.S., Nikitsky N.B. (eds.): Coleopterous insects (Insecta, Coleoptera) of Republic of Adyghea (annotated catalogue of species). Maikop: Adyghe State University Publishers. P.128-129 [in Russian with English Title].

Prokin A.A., Litovkin S.V., Jäch M.A. 2016 [2015]. New records of Hydraenidae and Elmidae (Coleoptera) from Russia and adjacent countries // Fragmenta Faunistica. Vol.58. No.2. P.99-110.

Shapovalov M.I., Prokin A.A., L'vov V.D. 2012. New data on the fauna of families Dytiscidae, Hydrophilidae and Dryopidae (Coleoptera) of the North Caucasus // Caucasian Entomological Bulletin. Vol.8. No.2. P.211-212 [in Russian, with English abstract].

Zaitzev Ph. 1934. [Uebersicht der Kaukasischen Vertreter der Unterfam. Dryopini] // Proceedings of Zoological Sector of the Georgian Department of Transcaucasian Branch of the Academy of Sciences of the USSR. P.1. P.33-45 [in Russian, with German Summary]. 